\title{
PREDICTORS OF SUSTAINED VIROLOGICAL RESPONSE (SVR) TO PEGYLATED INTERFERON ALPHA (PEG-IFN $\alpha$ ) AND RIBAVIRIN (RBV) IN PATIENTS WITH CHRONIC HEPATITIS C INFECTED WITH GENOTYPE 1
}

\author{
Krasimir Antonov, Deian Jelev, A. Ivanova, Zahariy Krastev \\ Clinic of Gastroenterology, St. Ivan Rilsky University Hospital, Sofia
}

\section{ABSTRACT}

Objective: The combined PEG-IFN alpha and RBV therapy achieved SVR in $40-50 \%$ of patients infected with HCV genotype 1. Identification of virological and host paramemeters predicting SVR will be useful to tailor therapy.

Methods: 71 patients with chronic HCV genotype 1 infection were treated with PEG-IFN alpha2a and RBV for 12 months. Predictors of SVR were analyzed by using nonparametric correlation test.

Results: SVR was found in 57 / 71 of subjects $(80,3 \%)$. The significant differences in baseline level of HCV RNA, sex, age, baseline ALT and present of liver cirrhosis between the patients with or without SVR were not found. Correlation was not proved between SVR and all these factors when they were analyzed separately. High correlation was found between serum levels of HCV RNA at the end of 3-th month therapy (Early Virological Response) and SVR ( $\mathrm{r}=0,759 ; \mathrm{p}=0,011)$.

Conclusion: The viral response during the first 3 months of PEG-IFN alpha and RBV therapy is the strongest independent predictor among the all baseline viral and host predictive factors for achieving of SVR.

Key words: HCV, HCV genotype 1, PEG-IFN, Ribavirin, predictors.

\section{INTRODUCTION}

Hepatitis $\mathrm{C}$ virus (HCV) infection is one of the main causes of chronic liver disease worldwide (1). It is estimated that approximately 130-210 million individuals are chronically infected with HCV (2). Chronic infection is associated with variable degrees of hepatic inflammation and fibrosis progression, regardless of HCV genotype and viral load. Depending on the presence of co-factors (alcohol consumption, diabetes mellitus, older age, HIV and HBV coinfections) between $10 \%$ and $40 \%$ of patients with chronic $\mathrm{HCV}$ infection will develop cirrhosis (3). Death related to the complications of cirrhosis is approximately $4 \%$ per year, whereas HCC occurs in this population at an estimated incidence of $1-5 \%$ pre year (4).

The combination of pegylated interferon alpha (PEG-
IFN $\alpha$ ) and Ribavirin (RBV) is the approved and well accepted standard-of-care $(\mathrm{SoC})$ for chronic hepatitis $\mathrm{C}(5,6,7)$. The primary goal of $\mathrm{HCV}$ therapy is to cure the infection, which results in eliminating detectable circulating $\mathrm{HCV}$ after cessation of treatment. Sustained virological response (SVR) is defined as an undetectable HCV RNA level $(<50 \mathrm{IU} / \mathrm{ml}) 24$ weeks after treatment withdrawal. In patients infected with HCV genotype 1,SVR rates after SoC are on the order of $40 \%$ in North America and 50\% In Western Europe in most trials. The SVR rates are considerably higher in patients infected with HCV genotypes 2 and 3 (65-82\%).

Many predictors of SVR in patients infected with $\mathrm{HCV}$ genotype 1 were analyzed (8). Identification of favorable predicting factors is of clinical importance.

\section{MATERIALS AND METHODS \\ Studied patients}

We studied 71 patients with chronic HCV genotype 1 infection treated with SoC (PEG-IFN $\alpha 2 \mathrm{a} 180 \mu \mathrm{g}$ once per week s.c. and RBV 1000 - $1200 \mathrm{mg}$ daily dose p.o.) for 48 weeks according National Health Insurance Program (tab. 1). All subjects initially were with active viral replication defined as detectable HCV RNA and histology proved liver disease. Coinfections with HBV, HDV and HIV were excluded.

Table 1. Baseline patients' characteristics

\begin{tabular}{|l|l|l|}
\hline $\begin{array}{l}\text { Number } \\
\text { of patients }\end{array}$ \\
\hline Gender & $\begin{array}{l}\text { Male } \\
\text { female }\end{array}$ & 35 \\
& $\begin{array}{l}\text { Median } \\
\text { (min. - max.) }\end{array}$ & $\begin{array}{l}31 \\
(18-63)\end{array}$ \\
\hline Age [years] & $\begin{array}{l}\text { Median } \\
\text { (min. - max.) }\end{array}$ & $\begin{array}{l}586118 \\
(3422-27400 ~ 000)\end{array}$ \\
\hline HCV RNA [IU/ml] & $\begin{array}{l}\text { Median } \\
\text { (min. - max.) }\end{array}$ & $\begin{array}{l}47 \\
(10-99)\end{array}$ \\
\hline ALT [U/l] & YesNo & 962 \\
\hline Liver cirrhosis & & \\
\hline
\end{tabular}




\section{Treatment response}

Sustained virological response (SVR) was defined as an undetectable HCV RNA level 24 weeks after treatment withdrawal analyzed by sensitive PCR (COBAS AMPLICOR or "real time" PCR).

Early virological response (EVR) was defined as HCV RNA undetectable at 12 week, maintained up to end of therapy (9).

\section{Statistics}

Predictors of SVR were analyzed by nonparametric methods and correlations.

\section{RESULTS}

SVR was achieved in 57 / 71 of subjects $(80,3 \%)$. The rest 14 / 71 of patients $(19,7 \%)$ did not achieved SVR.

The two groups of patients with or without SVR were compared each others by sex, age, ALT, baseline HCV RNA and present of liver cirrhosis (tab. 2)

Table 2. Baseline characteristics of patients with or without SVR.

\begin{tabular}{|l|l|l|l|l|l|}
\hline Parameters (Median) & Sex (m/f) & Age (years) & ALT (U/I) & HCV RNA (IU/ml) & Cirrhosis (Y/N) \\
\hline Patients with SVR & $29 / 28$ & 29,0 & 47,0 & 660000 & $6 / 57$ \\
\hline Patients did not achieved SVR & $6 / 8$ & 37,0 & 47,0 & 475351 & $3 / 14$ \\
\hline
\end{tabular}

Between the patients with or without SVR did not found differences in sex, age, ALT, baseline HCV RNA and present of liver cirrhosis (tab. 3).

Table 3. The differences between patients with or without SVR

\begin{tabular}{|l|l|l|l|l|l|}
\hline Statistics & Sex (p) & Age (p) & ALT $(\mathbf{p})$ & HCV RNA (p) & Cirrhosis (p) \\
\hline Mann-Whitney U & 0,593 & 0,088 & 0,593 & 0,435 & 0,275 \\
\hline
\end{tabular}

It was studied correlation between SVR and baseline factors before treatment (tab. 4).

Table 4. Correlation between SVR and baseline factors.

\begin{tabular}{|l|l|c|}
\hline & Spearman correlation & P value \\
\hline Sex & $\mathrm{r}=-0,064$ & $\mathrm{p}=0,597$ \\
\hline Age & $\mathrm{r}=0,204$ & $\mathrm{p}=0.088$ \\
\hline ALT & $\mathrm{r}=-0,064$ & $\mathrm{p}=0.597$ \\
\hline HCV RNA & $\mathrm{r}=-0,093$ & $\mathrm{p}=0.439$ \\
\hline Cirrhosis & $\mathrm{r}=0,300$ & $\mathrm{p}=0,278$ \\
\hline
\end{tabular}

The patients' gender, age, baseline ALT and HCV RNA, presents of liver cirrhosis were not predictor of SVR in our group of patients with chronic HCV genotype 1 infection.

We analyzed correlation between SVR and EVR in our group of patients (tab. 5).

Table 5. Correlation between SVR and EVR.

\begin{tabular}{|l|l|l|}
\hline & Spearman correlation & P value \\
\hline EVR & $\mathrm{r}=0,759$ & $\mathrm{p}=0,011$ \\
\hline
\end{tabular}

There were a strong correlation between EVR and SVR. The virological response at the end of 12 weeks SoC therapy predicted much better achieving of SVR than the baseline viral and host factors.

\section{DISCUSSION}

Pretreatment predictors of response are useful for advising patients on their likelihood of an SVR. Absence of favorable factors should not be used, however, to deny therapy. Data on predictor of an SVR come from several sources: registration trials which have strict inclusion and exclusion criteria and may not accurately reflect the general population infected with $\mathrm{HCV}$ and community-based trials that may not be conducted with same rigor as registration trials.

Multivariate analyses have identified two major predictors of an SVR among all population studied: the viral genotype and pretreatment viral load $(10,11,12)$. Our results did not confirm the importance of baseline HCV RNA levels for achieving SVR when single nonparametric analysis was used. This conclusion is supported by the last EASL Clinical Practice Guidelines for management of HCV infection (9). There was pointed that the strongest baseline predictors of SVR were: HCV genotype; genetic polymorphisms located in chromosome 19 (IL28B) and stage of liver fibrosis. In our studied group the number of patients with advance fibrosis 
(liver cirrhosis) is relatively low $-13 \%$. This could explain the absence of correlation between SVR and present of liver cirrhosis in our treated population. Other possible explanation for low number of cirrhotic patients in our group was their young age -31 years. This defined short duration of HCV infection. The high rate of SVR $-80 \%$ was likely due to low prevalence of cirrhosis and young age of our patients. The sex of patients was not independent predictor of SVR according the results of our treatment.

This study very clear showed the advance of viral response during SoC therapy above baseline viral and host factors to predict SVR. EVR significantly correlated with SVR. According the new EASL Clinical Practice Guidelines for management of HCV infection EVR defined 48 weeks treatment with SoC in patients infected with HCV genotype 1 (13). Treatment for all HCV genotypes should be stopped at week 12 if the HCV RNA decrease is less than $2 \log 10$ $\mathrm{IU} / \mathrm{ml}$. All this determinates that during SoC treatment, HCV RNA measurements should be performed more often during the first 3 months to help tailor treatment.

\section{CONCLUSION}

The viral response during the first 3 months of PEGIFN alpha and RBV therapy in patients with chronic HCV genotype 1 infection is the strongest independent predictor among the others baseline viral and host factors for achieving of SVR.

\section{REFERENCES:}

1. Lavanchy D. The global burden of hepatitis C. Liver Int. 2009 Jan;29 Suppl 1:74-81. [PubMed] [CrossRef]

2. Shepard CW, Finelli L, Alter MJ. Global epidemiology of hepatitis $\mathrm{C}$ virus infection. Lancet Infect Dis. 2005 Sep;5(9):558-567. [PubMed] [CrossRef]

3. Afdhal NH. The natural history of hepatitis C. Semin Liver Dis. 2004; 24 Suppl 2:3-8. [PubMed] [CrossRef]

4. Thompson CJ, Rogers G, Hewson P, Wright D, Anderson R, Cramp M, et al. Surveillance of cirrhosis for hepatocellular carcinoma: systematic review and economic analysis. Health Technol Assess. 2007 Sep;11(34):1-206. [PubMed]

5. Ghany MG, Strader DB, Thomas DL, Seef LB. Diagnosis, management, and treatment of hepatitis $\mathrm{C}$ : an update. Hepatology. 2009 Apr;49(4):1335-1374. [PubMed] [CrossRef]

6. Asian Pacific Association for the Study of the Liver (APASL) Hepatitis C Working Party, McCaughan GW, Omata M. Asian Pacific Association for the Study of the Liver consensus statements on the diagnosis, management and treatment of hepatitis C virus infection. $J$ Gastroenterol Hepatol 2007 May;22(5) 615-633. [PubMed] [CrossRef]

7. Sarrazin C, Berg T, Ross RS, Schirmacher P, Wedemeyer H, Neumann U, et al. Prophylaxis, diagnosis and therapy of hepatitis $\mathrm{C}$ virus (HCV) infection: the German guidelines on the management of HCV infection. Z Gastroenterol. 2010 Feb;48(2):289-351. Epub 2010 Jan 29. [Article in German] [PubMed] [CrossRef]

8. Manns MP, Wedemeyer H, Cornberg M. Treating viral hepatitis C: efficacy, side effects, and complications. Gut 2006 Sep: 55(9):1350-1359. [PubMed] [CrossRef]

9. European Association for the Study of the Liver. EASL Clinical Practice Guidelines: Management of Hepatitis C Virus Infection. J Hepatology. 2011 Aug;55(2):245-64. Epub 2011 Mar 1. [PubMed] [CrossRef]

10. Manns MP, McHutchison JG, Gordon SC, Rustgi VK, Shiffman M,
Reindollar R, et al. Peginterferon alfa- $2 b$ plus ribavirin compared with interferon alfa$2 \mathrm{~b}$ plus ribavirin for initial treatment for chronic hepatitis C: a randomized trial. Lancet. 2001 Sep 22;358(9286):958-65. [PubMed] [CrossRef]

11. Fried MW, Shiffman ML, Reddy KR, Smith C, Marinos G, Goncales FL, et al. Peginterferon alfa-2a plus ribavirin for chronic hepatitis C virus infection. $N$ Engl $J$ Med. 2002 Sep 26;347(13):975-982. [PubMed]

12. Hadziyannis SJ, Sette H Jr, Morgan TR, Balan V, Diego M, Marcellin P, et al. Peginterferon-alpha2a and ribavirin combination therapy in chronic hepatitis $\mathrm{C}$ : a randomized study of treatment duration and ribavirin dose. Ann Intern Med. 2004 Mar 2;140(5):346-355. [PubMed]

13. Mangia A, Minerva N, Bacca D, Cozzolongo R, Ricci GL, Carretta V, et al. Individualized treatment duration for hepatitis C genotype 1 patients: a randomized controlled trial. Hepatology. 2008 Jan;47(1):43-50. [PubMed] [CrossRef]

\author{
Address for correspondence: \\ Dr. Krasimir Antonov \\ Clinic of Gastroenterology, St. Ivan Rilsky University Hospital, \\ 15, Acad. Ivan Geshov Blvd., Sofia 1431, Bulgaria \\ Phone: + 3592952 6319; Fax: +359 28510816 \\ E-mail: krasi_antonov@abv.bg
}

